\title{
Scripture, style and persuasion in seventeenth-century English theories of preaching
}

Article

Published Version

Morrissey, M. (2002) Scripture, style and persuasion in seventeenth-century English theories of preaching. Journal of Ecclesiastical History, 53 (4). pp. 686-706. ISSN 1469-7637 doi: https://doi.org/10.1017/S002204690100149X Available at https://centaur.reading.ac.uk/25324/

It is advisable to refer to the publisher's version if you intend to cite from the work. See Guidance on citing.

To link to this article DOI: http://dx.doi.org/10.1017/S002204690100149X

Publisher: Cambridge University Press

All outputs in CentAUR are protected by Intellectual Property Rights law, including copyright law. Copyright and IPR is retained by the creators or other copyright holders. Terms and conditions for use of this material are defined in the End User Agreement.

www.reading.ac.uk/centaur

\section{CentAUR}


Central Archive at the University of Reading

Reading's research outputs online 
Fnl of Ecclesiastical History, Vol. 53, No. 4, October 2002. (C) 2002 Cambridge University Press 686 DOI : го.гі7/Soo2204690 Iо0I49X Printed in the United Kingdom

\title{
Scripture, Style and Persuasion in Seventeenth-Century English Theories of Preaching
}

\author{
by MARY MORRISSEY
}

\begin{abstract}
The distinction between a Puritan 'plain' and a Laudian 'metaphysical' preaching style rests on secular rhetorical theories of persuasion that are relatively unimportant to early Stuart homiletics but are central to later Latitudinarian polemics on preaching. Instead, the 'English Reformed' theory and method of sermon composition rests on the didactic function of preaching and the need for the Holy Spirit and hearers to co-operate with the preacher. Although Andrewes and some avant-garde conformists questioned this theory, they developed no alternative method of composition. Arguments made in the I65os for direct inspiration by the Spirit contributed to the decline of both theory and method.
\end{abstract}

The character of his Sermon is Holiness; he is not witty, or learned, or eloquent, but Holy. A Character that Hermogenes never dream'd of; and therefore he could give no precepts thereof.

George Herbert, A priest to the temple, I652

C ritics of seventeenth-century sermons have commonly divided preaching styles along the lines of the political and doctrinal divisions in the Church, associating the plain style with Puritans and what is now called the 'metaphysical' style with the Laudians (or 'avant-garde conformists'). This simplistic and flawed dichotomy can be shown to be based on the transferral of theories from classical rhetoric that were only partly relevant to discussions of preaching before the Restoration. Behind this transferral lies the assumption that preaching was always considered a branch of rhetoric, rather than a sacred office that makes use of the techniques of rhetoric: that it aims primarily to persuade the hearers through the use of the argumentative and ornamentative resources of oratory. But such a description is alien to the

This article was delivered as a paper to the Tudor and Stuart History seminar in Cambridge: I would like to thank the participants for their comments. I would also like to thank Patrick Collinson, Arnold Hunt, Jeanne Shami and Alan Cromartie for their help and advice. 
terms in which Elizabethan and early Stuart English preachers spoke of their task. This article argues that the unique status of preaching in Reformed theology set it apart from other forms of oratory and shaped the theory of preaching accepted within the mainstream of the English Church before the Civil War. The term 'English Reformed' will be used to describe the theory and the method of sermon composition that grew up from the Reformed doctrines of Scripture from which seventeenthcentury writers on the subject drew their ideas. ${ }^{1}$ This is not to say that there were no differences in preaching styles across the Jacobean Church nor that the avant-garde conformists did not try to reassess the role of preaching in public worship. ${ }^{2}$ None the less, the vast majority of writers on preaching before the Restoration refer to it as an event unlike any other oration in that there are three 'parties' to it, as Lancelot Andrewes put it, 'I. God, 2. the Preacher, and the Hearer'. ${ }^{3}$

The division between 'plain style' Puritan and 'metaphysical' Laudian preachers owes most to the influences of Perry Miller and W. Fraser Mitchell. ${ }^{4}$ It was they who tied this distinction to the intellectual prejudices and theologies of each group. In English pulpit oratory from Andrewes to Tillotson (I932), Fraser Mitchell used 'metaphysical' preaching as an extension of the term used to describe the poetry of Donne and Herbert, ${ }^{5}$ arguing that Donne, Andrewes and their fellow 'AngloCatholic' preachers turned from the 'barren logic of Calvin's Institutes' to the 'treasures of patristic and mediaeval preaching' by 'insisting on the continuity of the Church of England as part of that [Catholic] Church'. With this allegiance came a style of preaching as 'beautiful and effective imagery' and 'the evidences of lively and ingenious wit' were quoted and imitated. ${ }^{6}$ In The New England mind ( 1939), Perry Miller found in the 'Puritan plain style' a statement of opposition to the style and ecclesiology

1 The term 'English Reformed' is an extension of the 'new Reformed arrangement of Doctrines and Uses' identified by J. W. Blench. Blench wrongly thought that few preachers used this method, partly because he did not consider the question of style in relation to dispositio or homiletics: Preaching in England in the late fifteenth and sixteenth centuries, Oxford I 964, iо0-2.

${ }^{2}$ In particular see Peter Lake, 'Lancelot Andrewes, John Buckeridge, and avant-garde conformity at the court of James I', in Linda Levy Peck (ed.), The mental world of the facobean court, Cambridge I99 I, I I 3-33, esp. pp. i 23-6; Peter E. McCullough, Sermons at court: politics and religion in Elizabethan and facobean preaching, Cambridge i998, I 2 I-2, I $5^{8-66 .}$

${ }^{3}$ Lancelot Andrewes, XCVI sermons, London i629 (RSTC 6o6), I 30 (2nd pagination).

${ }^{4}$ Before Mitchell's and Miller's works, preaching styles prior to the I67os were thought to be more or less uniform. E. C. Dargan, for example, described the history of English preaching as an evolution from the 'pedantry' and 'affectation of style' of both Anglican and Puritan sermons to the easy, gracious plainness of Tillotson: A history of preaching, New York I905-I2, ii. I46.

${ }_{5}$ W. Fraser Mitchell, English pulpit oratory from Andrewes to Tillotson, London I 932, 4-5, I 48 .

${ }^{6}$ Ibid. I 40. 
of the Laudians. But Miller also maintained that the Ramism and keen anti-rhetorical prejudice of Puritans made them acutely anxious to limit the use of persuasive language in preaching and this, he claimed, had an immediate and obvious impact on their style. It divorced 'thought from expression', as their sermons were worked out 'in terms of logic' and only then 'punctuated' with rhetorical tropes.

Both Mitchell and Miller mapped the debate over preaching styles onto the age-old debate about the function and value of rhetoric: they assumed that preachers' use of rhetorical techniques implied that preaching was considered a rhetorical art, and so both writers devoted considerable attention to early modern education in logic and rhetoric. They assumed that the psychological theories that dictated forms of persuasion were shared by preachers and rhetors alike. Miller and Mitchell independently found that the dichotomy between persuasion by rational argument using a dialectical plain style and persuasion by moving the emotions through the use of a mellifluous style continued to dominate early modern discussions of rhetoric. Early modern writers who disavowed deliberate eloquence would, they argued, be taking an anti-rhetorical position. When Perry Miller and W. Fraser Mitchell projected the debate on rhetoric onto discussions of preaching, the result was a dichotomy between antirhetorical plain and rhetorical 'metaphysical' styles. Miller's Puritans, as good Ramists, thought of rhetoric as adding only ornamentation to an oration, ornamentation that could move the affections contrary to truth. Consequently, they restricted their use of the techniques of rhetoric to exhortations to the hearers. Ramist logic helped the preacher to dissect his text and present his doctrines. ${ }^{8}$ Mitchell's Anglo-Catholics abandoned the 'cold logic' of Calvin for a style that would move the affections by its beauty, a grandiloquence that is equated with an avowed use of the art of rhetoric. Unlike Miller, he can find no persuasive force in a dialectical plain style; it 'could only result, as it did result, in baldness and inelegancy of diction'. 9

Broadly speaking, the dichotomy established by Fraser Mitchell and Miller has determined the subsequent debate on preaching rhetoric. Horton Davies follows Fraser Mitchell in his work on the characteristics of metaphysical preaching, although he does insist that not all 'metaphysical' preachers were 'of the Arminian type'. ${ }^{10}$ Debora Shuger proposes two styles as dominant in the period i 560 to i620, a 'passionate plain style' and the 'Christian grand style', a dichotomy that generally operates within the framework established by Fraser Mitchell and

\footnotetext{
7 Perry Miller, The New England mind: the seventeenth century, repr. Cambridge, Mass. I 954, 332-3, 327 .

${ }_{9}$ Fraser Mitchell, English pulpit oratory, го г.

10 Horton Davies, Like angels from a cloud: the English metaphysical preachers, ${ }_{1580-1645}$, San Marino, CA. I986, I-3, 33-180.
} 
Miller. ${ }^{11}$ So it can be argued that underlying most discussion of seventeenth-century preaching is the distinction drawn from secular rhetoric between persuasion by the reason using a dialectical plain style or by the passions using a 'grand style'. ${ }^{12}$ This is not, however, accurately descriptive of early seventeenth-century theories of preaching. Reformed doctrines of Scripture created profound differences with classical theories of persuasion, making the latter inappropriate as a theoretical basis for homiletics.

In order to understand the precepts and advice offered in early modern preaching rhetorics, we must describe the preacher's role in terms of the doctrine of the Word, remembering its primary reference to the second person of the Trinity. God has chosen the 'foolishness of preaching' ( I Cor. i. 2 I) to make the Word operative in the Church. Preaching is, therefore, one of the primary means appointed by God (along with the sacraments) for the receipt of grace. ${ }^{13}$ For many Puritans, it was the essential means because faith was thought to be first given ordinarily during preaching. ${ }^{14}$ It is for this reason that attending sermons became so important: the event was an opportunity for grace even if the message delivered there had been heard many times.

There are two very important implications of this emphasis on the Word as Christ that are central to the English Reformed theory of preaching: first, it makes the Bible more than a means of information. Scripture is not merely a record of the sayings of Christ; it is a revelation of God under the 'veil' of its words. ${ }^{15}$ Consequently, preaching is more

11 Debora Shuger describes William Perkins as one of the 'more conservative' theorists and links the 'liberal Protestant' theorist with Tridentine rhetorics: Sacred rhetoric: the Christian grand style in the English Renaissance, Princeton 1988, 69-7 г, 108-9, 244.

12 Harold Fisch, 'The Puritans and the reform of prose-style', English Literary History xix (I952), 229-48. Although their studies are not restricted to sermons, Joan Webber and Stanley Fish have retained this dichotomy in their discussion of seventeenth-century prose, Fish in his distinction between 'self-satisfying' and 'self-consuming' prose works and Webber in her discussion of the 'Anglican' and 'Puritan' 'I': Joan Webber, The eloquent ' $I$ ': style and self in seventeenth-century prose, Madison i 968, 3-10; Stanley Fish, Self-consuming artefacts: the experience of seventeenth-century literature, Berkeley, CA. I 972, 376-8. Although he retains the 'plain' and 'witty' distinction, David D. Hall demonstrates clearly that 'plainness' is not to be understood 'in strict literary terms' but as 'a form of preaching modeled on the action of the Holy Spirit': The faithful shepherd: a history of the New England ministry in the seventeenth century, Chapel Hill r972, 52-5.

13 For Calvin's teaching on Scripture as revelation and on preaching as the means of its promulgation see Ronald S. Wallace, Calvin's doctrine of the word and sacrament, Edinburgh I 953, I-I 0, 82-95; Richard Muller, Post-reformation Reformed dogmatics, Grand Rapids, Mich. I 993, ii. I 92-4, 208-9.

14 Preaching is treated as the ordinary means of salvation by Stephen Denison, The new creature, London i6 69 (RSTC 6607), 53-4, and Thomas Cheaste, The way to life, London I6o9 (RSTC 5 I06), 28-30. For an extreme statement on the importance of preaching in this respect see Samuel Hieron, The dignity of preaching, in Works, London [1620?] (RSTC I 3377.5), 580-3. $\quad{ }^{15}$ Muller, Reformed dogmatics, ii. 60-I, 72-80, 208-Io. 
than merely informative on morality or godliness: the sermon was to make that particular part of Scripture operative for the hearers. For this reason, sermons were composed around a biblical text, and the preacher's role was partly the didactic one of showing the significance of the text to the hearers. In effect, the text delimited and defined the subject of the sermon. Second, if Christ was present in the Word and that presence made operative in preaching, it was not just because of the preacher's oratorical skills: the operative force in this encounter was the Holy Spirit, who gave the necessary grace to the hearers that enabled them to benefit from the sermon. But the hearers were not to be completely passive in this process. For a sermon to 'edify', they must pray for faith to be edified and attend diligently to what is said. Using a commonplace exposition of the Parable of the Sower, Heinrich Bullinger is explicit on this point:

We must pray continually, that the bountiful and liberal Lord will vouchsafe to bestow on us his Spirit, that by it the seed of God's word may be quickened in our hearts, and that we, as holy and right hearers of his word, may bear fruit abundantly to the glory of God, and the everlasting salvation of our own souls. ${ }^{16}$

Elizabethan and Jacobean preachers often reminded themselves and their hearers that in preaching it is God who gives 'the increase' (I Cor. iii. 6). Thomas Adams distinguished the healing message of the Gospel from its messenger. Preaching on Jeremiah viii. 22, he assured his hearers that:

It is the tidings we bring, that saves you, not our persons. Moses that gave the Law, could not frame his owne heart to the obedience of it. It lyes not in our power to beget faith in our owne soules. The heart of the King is in the hands of God, as are the waters in the South. The soules of all, Prince and people, Prophets and Nazarites, Preachers and hearers, learned and ignorant, are converted by God, by whom they were created. ${ }^{17}$

So although the preacher had a duty to try to persuade his hearers, actually moving them to fully accept and follow his teachings was beyond him. According to Reformed doctrine, human beings are incapable of believing the teachings of Scripture without the help of God. This is the argument presented by Thomas Granger in his Pauls crowne of rejoicing ( I6 I6). The first degree of faith, gained 'meerely of grace' Granger says, is to hear the Word preached, because 'the gracelesse, viz, naturall men,

${ }^{16}$ Heinrich Bullinger, Decades, ed. Thomas Harding (Parker Society, I 849-52), i. 66. These were made compulsory reading for all non-preaching ministers in the province of Canterbury by the convocation of I 586: Edward Cardwell, Synodalia, Oxford I 842, 542. On the means to an 'effectual hearing of the Word' see William Perkins, Cases of conscience, in Works, Cambridge r6r6-г8 (RSTC I965I), iii. 70-1; William Ames, Conscience, with the power and cases thereof, Leiden-London I639 (RSTC 552), 4.25-6; Thomas Shepard, Subjection to Christ in all his ordinances,... Together with a treatise of ineffectual hearing the Word, London I652 (Wing S.3 I 4 I), I 88-9 I. I owe my knowledge of this work to Professor David Hall.

17 Thomas Adams, The works of Tho[mas] Adams, London i63o (RSTC г05), 29I. 
will not patiently heare this word of the preaching of God'. The second degree of faith is to 'give assent in general to the same, as true', and this also is 'meerely of grace', as is the third degree, to 'embrace [it] with willingnes and liking, and to apply it to themselves' and the last, that is, to 'receive the word as from God, and not from Man'. ${ }^{18}$ As English preachers assumed that they addressed a 'mixed' congregation of converted and unregenerate, the Calvinists among them must have spoken with a working assumption that not all of their hearers would, or could, respond fully to their sermons. ${ }^{19}$ (Arminian preachers, however, could exhort the hearers directly to accept the grace that God offers to all.) This was the experience of Richard Greenham, as recounted by Samuel Clarke. Although Greenham preached on Mondays, Tuesdays and Wednesdays, twice on Sundays and catechised on Thursdays and Fridays, Dry Drayton produced very few converts to a sincere and evangelical faith. The cause of this failure, according to Clarke, was 'the untractableness and unteachableness of that people' ${ }^{20}$ The alternative, that the success or failure of a preacher was measured by the effect of his sermons on his hearers, was untenable because it would leave the operation of God's 'ordinance' wholly in the hands of fallible men. None the less, preachers' efforts in exhortation had to be guided by the assumption that the Spirit might choose that moment to work on the hearts of unconverted hearers. Arthur Lake offers an arresting solution to this problem in an ordination sermon, where he writes that 'in a Ministers Commission Grace is Universall; we should labour the conversion of all and every one: neither should any man except himselfe, but labour to bee in the number of that all to whom God sendeth'. ${ }^{21}$

The English Reformed theory does not stress the preachers' dependence on the Spirit to the extent that the preacher is thought to be directly inspired. A carefully nuanced relationship was defined between the preacher, the hearers and the Holy Spirit, as can be seen from the writings

18 Thomas Granger, Paul's crowne of rejoicing, or, the manner to hear the Word with profit, London I6 6 (RSTC I 2 I82), 5-Io. It is noteworthy on the question of quotation (see below) that Granger, a Puritan, refers to the Greek version of his text to facilitate his exposition while later condemning ostentatiously learned preaching and the use of Greek and Latin when the hearers cannot understand them (pp. 5, 7-8, 43, 55-9).

19 On English congregations as 'mixed auditories' see Perkins, The arte of prophecying, in Works, ii. 668; Richard Bernard, The faithful shepheard, London I62 I (RSTC I94I), Iо7-8. Joseph Hall makes such an assumption in The righteous mammon, when he explicitly addresses his sermon to those among his hearers who have been converted from worldliness and can receive his message: Works, ed. Philip Wynter, Oxford I863, v. I 27.

${ }^{20}$ Samuel Clarke, The lives of thirty-two English divines, London 1677 (Wing C.4539), I $2-\mathrm{I} 5$.

21 Arthur Lake, Sermons with some religious and divine meditations, London i629 (RSTC I5I34), 228 (2nd pagination). This statement is consistent with Lake's hypothetical universalist stance on predestination: Nicholas Tyacke, Anti-Calvinists: the rise of English Arminianism, c. I590-1640, Oxford I987, 93-5, 99 . 
of William Perkins. In The arte of prophecying, Perkins writes that two things are necessary to make preaching 'lively and powerful': the 'hiding of human wisdom' and 'the demonstration of the Spirit'. But Perkins is adamant that sermons should be devised with care and study and not be pronounced ex tempore. ${ }^{22} \mathrm{He}$ explains his idea of the "demonstration of the spirit' more fully in the first of his two treatises $O f$ the calling of the ministerie. There he writes that 'to speake in the demonstration of Gods spirit, is to speake in such a plainenesse, and yet such a powerfulnesse, as that the capacities of the simplest, may perceive, not man, but God teaching them in that plainenesse, and the conscience of the mightiest may feele, not man, but God reprooving them in that powerfulnes' ${ }^{23}$ This does not imply that the preacher is directly inspired in what he says, an idea that Perkins dismisses as 'Anabaptisticall fancies, and revelations which are nothing, but either dreames of their owne, or illusions of the Devil' (p. 43 I). The words of a human preacher are God's chosen means of revelation. God's spirit, Perkins says, "worketh not but upon the foundation of the word: onely I teach this, that a Minister must be a divine Interpreter, an Interpreter of Gods meaning' (p. 43 I). So the words that the preacher delivers are not plain and powerful because they are the voice of God unmediated by the preacher, but because they show the preacher's attempt to interpret and explain the truths contained in Scripture in a way that all of his hearers can understand and that most powerfully demonstrates his conviction of that truth. (As well as an interpreter, the preacher is 'a faithfull witnesse of God', p. 435.) Nor does Perkins make his description of the preacher's duty a prescription for successful preaching: he describes the hearers' obligation also. They are to hear their ministers 'gladly, willingly, reverently and obediently' (pp. 430-I). I would argue that Perkins's ideal of a sermon in which the Spirit is demonstrated, or manifest, is not one that is in danger of making the preacher a 'passive medium' for the Spirit. ${ }^{24}$ What Perkins is demanding is that the preacher deliver his sermon in an unostentatious way with a primary concern to teach and exhort his hearers, not to demonstrate his learning. If, as he should sincerely wish and pray, the spirit gives him grace to preach 'to edification', then that Spirit will be evident (and so 'demonstrated') in his sermon, making it powerful and effective on all well-disposed hearers.

But if it is the Spirit who 'gives the increase', and both preacher and hearers have to pray for the spirit's co-operation, what is the preacher's task when he stands in the pulpit? English writers on preaching are consistent in what they describe as the preacher's duty. William Perkins's

${ }^{22}$ Perkins, Arte of prophecying, 670.

${ }^{23}$ Idem, Of the calling of the ministerie, in Works, iii. 430.

${ }^{24}$ Shuger argues that Perkins's theory meant that 'the preacher would fade into a passive medium for a divine "force", : Sacred rhetoric, 70. For a more accurate description of Perkins's homiletics see Hall, Faithful shepherd, 54-5. 
summary of the 'art of prophesying' is well known: the preacher was to 'reade the Text distinctly', to 'collect a fewe and profitable points of doctrine out of the naturall sense' and 'apply' those doctrines 'to the life and manners of men in a simple and plaine speech'. At the other side of the political spectrum, John Whitgift, in his Defense of the aunswere to the Admonition, gives as 'the usual signification' of 'preacher', 'him that interpreteth the Scripture, teacheth, and exhorteth in the Congregation, by discoursing upon the scriptures, and applying them as occasion serveth'. Finally, John Wilkins, the last person to write on this method of sermon composition, gave a similar definition with great economy in his handbook Ecclesiastes ( I646): the 'principall scope' of the 'divine orator' was to 'Teach clearly, Convince strongly. Perswade powerfully', and so 'the chief parts of a Sermon' are 'Explication, Confirmation, Application' ${ }^{25}$ This summarises the art of preaching in the Elizabethan and early Stuart Church: it was an act of biblical interpretation whereby the teachings of the Bible were made relevant (or applied) to the circumstances of the sermon and to the hearers' lives.

The doctrinal basis is of fundamental importance to English Reformed preaching theory: it reveals the nature of God's salvific plan and shows how that should dictate actions. It is for this reason that Jacobean preachers developed a method of composition particular to preaching, which aligned the preacher's advice on life and morals with his biblical text. The preacher first 'divided' the biblical text on which he spoke, that is, he distinguished the words or phrases from which the main points would be taken (or rather, in which the doctrines to be expounded were found). These sections of the text were then dealt with in detail in the main part of the sermon, in which the scriptural text was shown to contain certain precepts: this was called the 'explication' of the text. The precepts thus 'uncovered' were then applied to the hearers' lives or to the circumstances of the day (the 'application' of the doctrines). Although these principles did not necessarily dictate the structure of the sermon (an explication, followed by an application ending in an exhortation and prayer), in the simplest of sermons this was the case. For this reason, such sermons were said to use, in Abraham Wright's phrase 'the plaine easie way of Doctrine and Use'. ${ }^{26}$ More complicated ways of structuring sermons were used, sometimes through a manipulation of the order of the words of the text in the division or by intermingling explication and application throughout the sermon. None the less, such elaborate compositions still demonstrate the assumption that the preacher's task was to explain the words of the text and apply them to the circumstances of his sermon.

${ }^{25}$ Perkins, Arte of prophecying, 673; John Whitgift, The defense of the aunswere to the Admonition, London I574 (RSTC 25430), 575; John Wilkins, Ecclesiastes, or a discourse concerning the gift of preaching, London 1646 (Wing W.2 I88), 5 .

26 Abraham Wright, Five sermons in five several styles, London I656 (Wing W.3685), A3r. 
The description of preaching as an exercise in explication and application meant that there was both a didactic and an exhortatory element in most sermons, which paved the way for both an unfigured, expository style in explication but also a more vehement, more highly figured style in exhortation. None the less, the assumption that the starting place of the sermon's argument (and the proof of that argument) lay in its explication of a scriptural text did emphasise the didactic aspect of preaching, and from this, primarily, came a concomitant emphasis on plainness. To teach, the preacher must speak in a way that will be understood, and so an appropriate 'plainness' rather than an identifiable 'plain style' was a virtue that most preachers avowed, because it made them better teachers. The arguments for plainness, then, arise less out of a wish to appeal to the reason of the hearers than from a wish to demonstrate the scriptural basis of all that the preacher says.

Although preaching was not considered a branch (or genus) of rhetoric, this does not mean that preachers were thought to have no need for deliberate eloquence. Particular importance was attached to the exhortation of hearers to follow the doctrines presented in a sermon, and here the techniques of rhetoric were most often called to the service of the preacher. Preachers were advised to exhort their hearers partly by presenting compelling arguments for the advice delivered, but also through the use of a more vehement style. In The faithful shepheard ( I607) Richard Bernard advises the preacher to 'use perswasions and exhortations' after he had proved his doctrines and also to use the resources of rhetoric to this end. But Bernard is only advising the use of the techniques of rhetoric, the 'engins of that Arte and grace in speaking'. ${ }^{27}$ He does not imply that preaching is itself a branch of rhetoric, an 'art' of speaking well. The preacher uses the arts of logic, rhetoric and grammar as best suits his pastoral purpose, just as the theologian uses the liberal arts as handmaids to the 'Queen of Sciences'.

Even with this allowance for using the 'arts of speech', numerous occasions could arise when a ruthlessly unadorned style could impede the preacher's aim. A learned auditory, for example, might be bored by a sermon perfectly suited to an unlearned audience. The governing idea in most seventeenth-century discussions of preaching styles is rhetorical decorum. This dictated that a preacher's style and theme were 'fit for the hearers ... agreeing to the persons, the time and the place', as Richard Bernard advises. ${ }^{28}$

${ }^{27}$ Richard Bernard, Faithful shepheard, London i6o7 (RSTC i939), 66. To an extent, Perry Miller was right to suggest that in 'plain style preaching' formal rhetoric was deployed in the application of doctrines: New England mind, 346-9. I argue that it was not restricted to this part of the sermon; nor did this mean that the rest of the sermon was antirhetorical.

28 Bernard, Faithful shepheard ( I62 I edn), i i6. 
The importance attached to decorum can help us unravel some of the issues at stake in the tangled debate over the use of quotations from extrabiblical sources. Many Puritan writers considered the use of quotations in Latin and Greek from the church Fathers (and, even more, from pagan writers) to be inappropriate in preaching before most auditories for two reasons: first, the auditory might not understand the words, and second, they might not understand the difference in authority between the quotations, which would lead them to confer on the writings of men the esteem that belonged to Scripture alone. For this reason, Samuel Hieron condemned the use of quotations from Fathers and pagans in sermons, because he says what 'makes preaching honourable in the hearts of Gods people' is 'their understanding it, so as that they may feele the sweetnes of it, and receive comfort by it'. ${ }^{29}$ Statements like this have been interpreted, then and now, as showing that all Puritans placed a complete ban on quotations from anything other than the Bible. ${ }^{30}$ The position articulated by most Puritan writers on this subject is far more careful, however. William Perkins advised that the use of 'humane testimonies, whether of the Philosophers, or of the Fathers' should be used only when they are the most likely means 'to convince the conscience of the hearer'. William Ames writes that 'in the ordinary course of Preaching, among auditors that are unskilfull in such matters', quotations from pagan writers are to be 'altogether ... abstained from'. Quotations from the church Fathers cannot be used as proofs, or, among common hearers, as illustrations or for 'ornaments sake'. They can, however, be used 'to convince the pertinaciousnesse of some, to refute the slanders of the enemies, and to helpe the weakenesse of others', provided that the preacher makes it clear that he is 'compelled to goe out of the bounds of the Scriptures'. ${ }^{31}$ This principle was considered too restrictive by many conformist writers, who allowed the use of quotations more generally provided they were translated or the auditory a learned one. The question

29 Hieron, Dignity of preaching, 585-6.

30 In his report on his examination by Archbishop Abbot, John Howson claimed that Puritans forbad all use of quotation, an allegation that James I agreed with but that Archbishop Abbot ridiculed: 'John Howson's answer to Archbishop Abbot's accusations', ed. Nicholas Cranfield and Kenneth Fincham, Camden Miscellany XXIX (Camden $4^{\text {th }}$ ser. xxxiv, I 987), 320-4I, 333-4. This exchange shows the complexity of the problem: - which Abbot rejects - Howson's and James's insistence that Puritans disallow quotation demonstrates that there was a widespread perception that Puritans placed a ban on all extrabiblical quotation or citation. Elsewhere, Abbot's position echoes Perkins, when he argues that although 'some men of learning have disliked the over-much heaping up of Sentences out of the Fathers, to no purpose or needlessely, \& especially if it have bin done in Latin or Greeke, when Sermons are made to the ordinary people in the vulgar tongue', the 'judicious' uphold this opinion in so far as it is 'the abuse' and not 'the use' of the Fathers that is criticised: The reasons which Doctour Hill hath brought, for the upholding of papistry, ... unmasked, London i6o4 (RSTC 37), 37 I-2; see also pp. 418-i 9.

31 Perkins, Arte of prophecying, 664; Ames, Conscience, 73-4 (3rd pagination). 
of ostentation in the display of learning was countered by arguments for the importance of the church Fathers in the Church's exposition of Scripture and teaching on morality. In a sermon preached at St Giles Cripplegate in I 593, Lancelot Andrewes dismisses as an 'imagination' the idea of some hearers that they 'must heare no Latine, nor Greeke; no, though it be interpreted' and insists on the importance of arguments from the Fathers and pagan writers. ${ }^{32}$ Similarly, in a Paul's Cross sermon of i6 Io, Thomas Myriell criticises those who make use of the Fathers without referring to them, as such preachers effectively 'father [the Fathers' interpretations] all upon themselves'. The use of quotation, as with other aspects of preaching styles, was to be determined by rhetorical decorum and the primary duty to teach and exhort. It was in balancing these goals that disputes arose.

Of course, it would be wrong to suggest that the debate over quotations was the only, or the most important, point of contention between Elizabethan and early Stuart churchmen with regard to preaching. For many, the importance given to preaching by some Puritan writers proved unpalatable. What remains to be discussed is whether this debate resulted in a theory of preaching, and whether that theory gave rise to a method of sermon composition different from that described here as 'English Reformed'.

The uniqueness of preaching as the means of acquiring saving knowledge for the Puritan movement was one of the issues debated between John Whitgift and Thomas Cartwright in the Admonition Controversy in the early i57os. ${ }^{33}$ In his Defense of the aunswere, Whitgift awards no precedence to preaching as a means of grace, but writes that 'both preaching therefore and reading be meanes whereby God doth call to salvation those that be his'. ${ }^{34}$ A generation later, Richard Hooker made the same point in the Laws, writing that 'wherein whatsoever fitt meanes there are to notifie the mysteries of the worde of God, whether publiquelie (which we call preaching) or in privat howsoever, the worde by everie such meane even ordinarily doth save' ${ }^{35}$ But Hooker takes Whitgift's argument much further when he suggests that the reading of Scripture might be of more benefit to the hearers, as it is unmediated (and so not misinterpreted)

${ }^{32}$ Andrewes, XCVI sermons, 3 $\mathrm{I}^{-2}$ (2nd pagination). He makes the same point about quotations from the Fathers, in more strident terms, in his Concio ad clerum in synodo provinciali cantuariensis of I593: Opusculum quaedam posthuma, London i629 (RSTC 602), 32-3; Thomas Myriell, The devout soules search, London i6 го (RSTC I8323), 34-5.

${ }^{33}$ On the Admonition Controversy see Patrick Collinson. The Elizabethan Puritan movement, repr. London I 982, I I 7-2 I, I 3 I-40. On Hooker's use of Whitgift's argument see Peter Lake, Anglicans and Puritans? Presbyterianism and English conformist thought from Whitgift to Hooker, London I 988, I62-4. ${ }_{34}^{34}$ Whitgift, Defense of the aunswere, 572-3.

${ }_{35}$ Richard Hooker, Of the laws of ecclesiastical polity. (The Folger Library edition of the works of Richard Hooker, gen. ed. W. Speed, Cambridge, Mass. I 977-82), ii. 85; ii. 86-7, 92. 
by the preacher. ${ }^{36} \mathrm{He}$ also seems to suggest that the salvific function of Scripture, read or preached, stems from the information that it imparts, rather than from the operation of grace on those present. Scripture 'serveth than onlie in the nature of a doctrinall instrument. It saveth because it maketh wise to salvation'. ${ }^{37}$ This is clearly a very different argument from the one advanced by Whitgift: if sermons are 'doctrinall instruments' (in Hooker's phrase) then they are means of salvation only insofar as they teach the hearers what is required to be saved. The event of the sermon is not itself an opportunity for the receipt of grace, a critical point for the English Reformed theory of preaching.

The most famous preacher against preaching, and the clearest link between Hooker and the avant-garde conformists, is Lancelot Andrewes. ${ }^{38}$ Andrewes's opinion is difficult to establish because of its diffusion throughout his sermons, but it does contains obvious elements of the English Reformed theory of preaching. None the less, Andrewes's positioning of preaching, particularly in relation to prayer, does point its demotion as a means of grace.

The traditional elements in Andrewes's discussions of preaching are his inclusion of it among the 'meanes to procure the Spirit's comming' along with prayer and the sacraments. ${ }^{39} \mathrm{He}$ also follows the main current of English Reformed thinking on preaching by insisting on the connection between the Word that is Christ and the word of Scripture that is made effective to the hearers in the sermon by the Holy Spirit. In a sermon delivered on Whitsunday in 16 1 2 , he writes:

The Holy Ghost is Christ's Spirit, and Christ is the Word. And of that Word, the word that is preached to us, is an abstract. There must needs be a neernesse and alliance, between the one and the other. And indeed (but by our default) the Word and the Spirit (saith Esay) shall never faile or even part; but one be received, when the other is. We have a plaine example of it this day, in S Peter's auditorie, and another, in Cornelius and his familie (Acts $\mathrm{X}$ ) even in the sermon-time, the Holy Ghost fell upon them, and they so received Him. ${ }^{40}$

Andrewes's most emphatic and repeated complaint against preaching was one that was common to many other preachers: the hearers approached the sermon as entertainment and were passive in the event. In his most famous attack on sermon-centred piety, preached before the king at Greenwich in $1607,{ }^{41}$ Andrewes complained that they were 'hearers' but

${ }^{36}$ Ibid. ii. 99. This point was disputed by the writer of $A$ Christian letter, in Works, iv. $33^{-5}$.

${ }^{37}$ Hooker, Ecclesiastical polity, ii. 84

${ }_{38}$ On Andrewes's connections with Laudians see Tyacke, Anti-Calvinists, I I 3 -I 4, i66-7, г9o, and 'Archbishop Laud', in Kenneth Fincham (ed.), The early Stuart Church, I6o3-I642, London r 993, 5 I-70, 62-4; Lake, 'Lancelot Andrewes, John Buckeridge', i I 4.

39 Andrewes, XCVI sermons, 6o7, 6o9. $\quad{ }^{40}$ Ibid. 648.

41 Ibid. I 29-42 (2nd pagination). For a fully contextualised account of this sermon see McCullough, Sermons at court, I59-63. 
not 'doers' of the word. His insistence on the necessity of hearing the word continually and receiving it meekly (p. I 32 ) shows Andrewes broadly agreeing with his Puritan contemporaries that hearers and preacher must co-operate with the Spirit. Like them, he states that all sermons should be applied to the hearers' lives: there is, he says, 'no Article of Faith, or Mysterie of Religion at all, but is as a key to open, and as a hand to lead us to some operative vertue'. Andrewes emphasises (in fact it is the main argument of this sermon) that the effect of this attentive and active hearing is a growth in godliness, and it is godliness in general that Andrewes's defines as the 'doing' of the word. ${ }^{42}$ Likewise, in the seventh Ash-Wednesday sermon, he clearly states that 'the onely true praise of a Sermon is, some evill left, or some good done, upon the hearing of it'. ${ }^{43}$

It is through his comparisons of preaching with the other means of grace that Andrewes's demotion of preaching becomes evident. Andrewes reminds his hearers that in the ancient Church not all ministers were preachers, and elsewhere he notes that only catechumens and those outside the Church were allowed to attend sermons. ${ }^{44}$ More particularly, it is in describing the relationship between preaching and prayer that Andrewes comes closest to Hooker's position, treating preaching as a means to prayer rather than a means of grace in its own right. ${ }^{45}$ There is an extended discussion of this point in the eleventh of the Whitsunday sermons, preached in $1618 .{ }^{46}$ Here Andrewes takes the order of the statements in the text (Acts ii. I6-2 I) to show the relative importance of those ordinances. The text first says 'I will pour out of My Spirit; and they shall prophesy' and later states that 'whosoever shall call on the name of the Lord shall be saved'. In this way, Andrewes links 'prophecy' and 'invocation' from his text. Prophecy, that is preaching, and invocation, or prayer, are both means appointed to salvation, but they 'stand subordinate' as means (p. 7i6), because it is prayer that the text presents as the means of salvation: 'there is the quicunque (Quicunque invocaverit) and no where els' (p. 7I 7). ${ }^{47}$ Despite the eirenic assertion that 'I love not to dash one religious duty against another' (p. 720), Andrewes clearly makes preaching a means to prayer.

Although Andrewes does not abandon the evangelical element in preaching, his subordination of preaching to prayer in particular makes

42 Andrewes, XCVI sermons, I37.

44 Ibid. 34 (2nd pagination), 992.

43 Ibid. 242 .

45 This point has been noted by Peter Lake in 'Lancelot Andrewes, John Buckeridge', I 26 . 46 Andrewes, XCVI sermons, 710-2 I.

47 Andrewes is adroitly using the principle that the preacher base all his teachings on his explication of the text to demote preaching in the life of the Church. Similarly, Peter McCullough has shown that the arrangement of the sermons in XCVI sermons by Andrewes's editors, Laud and Buckeridge, effectively subordinates sermons to the liturgy: 'Making dead men speak: Laudianism, print, and the works of Lancelot Andrewes,

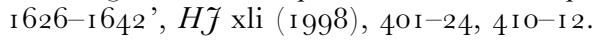


it more a means to prayer than an instrument of grace in its own right. His stress on its use to show the people how to 'call upon the name of the Lord' is also close to Hooker's argument that preaching is a 'doctrinall instrument'. His use of an image of ears being 'filled and even farced with' sermons points to the inevitable conclusion of Hooker's argument: it is possible to hear too many sermons, a problem not encountered with God's other ordinances. ${ }^{48}$

These arguments are to be found in the sermons of other avant-garde conformists. In his controversial I 598 Paul's Cross sermon, John Howson insisted that the emphasis on sermons in contemporary religious culture, and the neglect of prayer that went with it, resulted in the means to the service of God being preferred before the end, prayer, 'and', Howson argues, 'the rule is Semper finis excellit id quod est ad finem'. ${ }^{49}$ Richard Meredeth argued extensively for the subordination of sermons to prayer in a court sermon published in I6o6. He claims the authority of St Paul (paraphrasing 2 Tim. iii. I6) to insist that "the end of preaching is to teach men to live well \& vertuous $[s i c]$ '. ${ }^{50}$ Like Hooker, and far more than Andrewes, Meredeth denies preaching any evangelical purpose and makes it a mere means of informing the hearers. Henry King seems to present a similar opinion in his Paul's Cross sermon of I62 I, in which he argues that his hearers were guilty of listening to too many sermons. Using startling images of gluttons suffering from 'surfets' from 'too full feeding', similar to, though far more emphatic than Andrewes's 'farced' ears, King argues that people hear more at sermons than they can understand or remember. ${ }^{51}$ The event of the sermon is of no consequence; the purpose of preaching is to inform the hearers, and therefore it has limited use in the Church. This is a real departure from the Reformed theory of preaching, because it silently dismisses the role of the Holy Spirit in the event of the sermon. Because preaching is merely a means to acquire saving knowledge, the sermon is not, as Puritans had argued, a primary means of grace. Nor is it conceptually different from any other sort of oration that exhorts to virtuous action.

These arguments in opposition to the sermon-centred piety of early Stuart England cannot be said to produce a new method of sermon composition: Andrewes, Laud and Buckeridge all leave evidence in their sermons of using the principles of dividing, explicating and applying their

48 Andrewes, XCVI sermons, 70, 240.

${ }^{49}$ John Howson, A second sermon, preached at Paules Crosse, London I598 (RSTC I 3883), 43 .

50 Richard Meredeth, Two sermons preached before his Majestie in his chappell at Whitehall, London I6o6 (RSTC I 7832), 45. Ironically, 2 Timothy. iii. i6 is a crucial text in the development of the English Reformed method of preaching: Mary Morrissey, 'Rhetoric, religion and politics in the St Paul's Cross sermons, I603-1625', unpubl. PhD diss. Cambridge I998, I 5-i 6.

${ }^{51}$ Henry King, A sermon preached at Pauls Crosse, London i62 I (RSTC I4969), 3-7, 4. 
biblical text that lay at the heart of the English Reformed method of sermon composition. This is often manifested in the marginalia of the printed sermons: in all but five of the sermons in Andrewes's XCVI sermons, the division of the text is clearly marked in the margin, and many of them note the applications also. ${ }^{52}$ Whether Andrewes or his editors were responsible for the marginal notes is not clear. In Laud's own sermons, although no marginal notes signal the division of the text or the application, these exercises are clearly presented in the body of the sermon. ${ }^{53}$ So too with Buckeridge's funeral sermon on Andrewes: in keeping with common practice in funeral sermons, he explicates his text before applying it to the occasion and this is denoted by the word 'applicatio' in the margin. ${ }^{54}$ Although the avant-garde conformists did offer a challenge to the English Reformed theory of preaching, this did not translate into a new method of sermon composition: that change came with the Restoration.

What caused that change was the dissolution of the carefully articulated theory of the role of the Spirit in preaching during the Civil War, when the avowal of direct inspiration prised apart the balanced roles of the preacher, hearer and Spirit in the English Reformed method. The moment of this shift can be seen in the debate between William Dell and Joseph Sedgwick in Cambridge in I653. In The stumbling-stone, delivered in Cambridge in I653, William Dell, Master of Gonville and Caius College, puts forward an extreme version of the topos that the efficacy of preaching is dependent upon the operation of the Spirit. He argues that those who are given the grace to receive the Word have not only a better, but a different understanding of it than carnal people:

Now when God teacheth us his word Himself, we have an other understanding of it than other men who hear and read the same outward words, and yet want that

\footnotetext{
${ }^{52}$ The exceptions are sermons 6, I 4 and I 7 on the resurrection (although the latter two have roman numerals to note the division, 532,567 ) and the second and third sermons on several occasions. The application (or 'use' or 'the duty', or 'our duty') are noted in the margins on pp. 8, I 5, 42, 5 I, 6o, 69, 79, I 36, I 55 and I57, I68, 223, 255, 330, 362, 402,

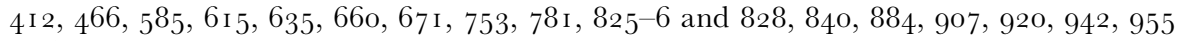
and 83 , I 26 (2nd pagination).

${ }_{53}$ William Laud, Seven sermons preached upon severall occasions, London I65 I (Wing L.598). Divisions are found on pp. 4-5, 50, 98-9, I 49, I 95, I 46 and 29 I. In sermons I, 3, 4, 5 and 6 Laud interspersed the applications after the explication of each point, but in sermons 2 and 7 , he placed an applicatory section after the main explication, beginning on pp. 85, 333 .

54 Andrewes, XCVI sermons, I6 (3rd pagination). This strategy was also used by preachers of funeral sermons in order to reconcile the different aims of exhortation and commemoration: Jessica Martin, 'Izaak Walton and his precursors: literary study of the emergence of the ecclesiastical life', unpubl. PhD diss. Cambridge r 993, I6-3 I. Buckeridge marks the division of the text using numerals $(\mathrm{I}-5)$ in the margin in his sermon on kneeling: A sermon preached before his Majestie at Whitehall, March 22, I6I7, London I6 I8 (RSTC 4005), 2.
} 
inward Teaching; For then have we the spiritual meaning of the Word, and the very mind of Christ in it, which others want, that are not so taught; And this offends the carnal Christians grievously, that the spiritual Christians have another knowledge and understanding of the Word then they. ${ }^{55}$

Human learning is of no use in understanding the Word and 'this Spirit alone is sufficient, both to enable us to know clearly and certainly the things of God, and also to publish them unto others'. Consequently, preaching can be performed 'in all places alike ... by all persons alike, who are true believers' ${ }^{56}$ In The tryal of spirits ( 1653 ), the focus of Dell's attack is the order of ministers itself and the universities in particular. Repeating his earlier assertion that the Word has a different meaning for those 'in the spirit', he writes that 'false Prophets, though they speak the word of the letter exactly, and that according to the very Originall, and curiosity of Criticismes, yet speaking it without the Spirit, they are false Prophets before God and his true church' ${ }^{57}$ Dell expounds a theory of direct inspiration. Among the errors he attributes to Sydrach Simpson, Master of Pembroke Hall and a leading Independent minister, is the opinion 'that men now are to get knowledge by studies and humane learning, and not by inspiration'. ${ }^{58}$ There is in Dell no careful balancing of the preacher and hearer's duty: the hearer must already be 'in the spirit' even to understand the spiritual import of the Word.

Dell was answered by Joseph Sedgwick in a sermon preached in Cambridge later in I 653. In the extended, printed version, Sedgwick uses arguments common to the tradition of the English Reformed theory of preaching, but he also uses some that point forward to the attack on Nonconformist preaching during the post-war era. He defends the use of quotations in foreign languages by preachers within the limits accepted by most writers before the war. Before an unlearned audience, it may show vanity but 'this is no prejudice, if they afterward interpret it to the people'. Before a learned auditory, however, there are good reasons for using quotations in the learned languages: 'Must it needs be ostentation here to confirme an exposition of the Word of God from the originall Text, or to shew that this is not onely their private fancy. ${ }^{59}$ Dell's definition of the preacher's duty is also consonant with earlier writers: the preacher is to 'expresse our thoughts accommodately to the hearers, to perswade, urge and convince, to discover the consonancy and harmony of Scripturetruths, to presse truth home upon the minds of men' and these are 'things

55 William Dell, The stumbling-stone, or, a discourse touching that offence which the world and worldly church do take against I. Christ Himself, London I653 (Wing D.930), i6.

56 Ibid. 25, I9.

57 Idem, The tryal of spirits, both in teachers and hearers, London I653 (Wing D.93 I), I9.

${ }^{58}$ Idem, A plaine and necessary confutation, in The tryal of spirits, 2.

59 Joseph Sedgwick, A sermon preached at St Maries in the University of Cambridge May Ist I653, or, an essay to the discovery of the spirit of enthusiasme, Cambridge I653 (Wing S.2362), 6. 
acquirable by art' but their efforts in this stand 'in conjunction with due dependance upon the Spirit, and his enlightning our souls'. The hearer is not to rely solely on the direct inspiration of the Spirit, nor is the Word totally inaccessible to the hearer without prior enlightenment: that argument 'makes all preaching and publishing of truth to no purpose' ${ }^{60}$ In an appended argument for a learned ministry, Sedgwick describes the 'office of the minister' as being 'to search into the will of God revealed already, declare, explain and presse the Truths already divulged by the Apostles', which Truth is 'delivered in Scripture in undoubted plainnesse' ${ }^{61}$

It is the didactic function of preaching that leads Sedgwick to the argument for plainness of style, but here we also see how close Sedgwick stands to the arguments about preaching after the war, for now it is the enemies on the left who are accused of not speaking plainly. This breach of decorum is not brought about by the excessive use of quotations or rhetorical ornament, however, but by their 'impertinent heaping up of Scriptures' and the 'noise of their speech and the heat of their passions'. These stylistic failures cover up their inability to explain and prove their teachings from the Word, the didactic function that led to the arguments for plainness before the war:

They use words of deceit, subtilty and ambiguity. How do those men love to walk in the clouds, to speak above the understandings of men, off and on, with an industrious kinde of confusion? Is this the plainnesse and simplicity of a Gospelpreacher? is this for edification, to give such an uncertain sound, to leave the hearers in a mist of words and dark expressions? are these interpreters of the revealed will of God, when the very Text it self is more easie, plain and familiar ${ }^{62}$

So the complaints about the Enthusiasts not preaching plainly arose out of the same argument for plain preaching associated with Puritan writers before the war, and those arguments rest on the didactic function of preaching. The preacher needs to speak plainly so that his hearers could understand how the application of his text derives from the inspired Word.

After the Civil War, the English Reformed theory and method of preaching were attacked from another direction. The conformist attack on Nonconformist preaching did not distinguish between the English Reformed method of preaching and the 'Enthusiasts' appeal to direct inspiration. There is a polemical edge to the distinction between preaching styles as they are presented by the conformists, especially those nonLaudian conformists traditionally called 'Latitudinarian' ${ }^{63}$ In Joseph

${ }^{60}$ Ibid. I 4, 24, 25 .

${ }^{61}$ Idem, Learning necessity to an able minister of the Gospel, in Sermon, 48.

${ }^{62}$ Idem, Sermon, 9, Io.

${ }^{63}$ This article does not address the question of whether 'Latitudinarianism' was a genuine distinctive current of thought. 
Glanvill's An essay concerning preaching ( 1678 ), Simon Patrick's A friendly debate between a conformist and non-conformist ( 1669 ) and John Eachard's The grounds and occasions of the contempt of the clergy ( 1670$)$ and A free and impartial inquiry ( I673), Nonconformist preaching is denounced as fanatical and irrational in terms that belie the moderation that their writers espouse. Eachard's A free and impartial inquiry is less concerned to identify, as its title promises, 'the causes of the very great esteem and Honour that the Nonconforming Preachers' are given by their followers than it is 'to reclaim their followers' ${ }^{64}$

The aim of these pamphlets is to convince the readers that Nonconformist preaching is an error-laden and destructive force in the English Church. To do so, they replace the charismatic element in Reformed preaching theory with the reintroduction of the distinction between persuasion by the reason or by the passions commonly made in secular rhetoric. ${ }^{65}$ This is then used to suggest that Nonconformist preachers are fraudulent sophists, persuading their hearers by their emotional language and extravagant expressions. Simon Patrick's conformist speaker in A friendly debate informs his Nonconforming neighbour that the latter's persuasion by Nonconformist preachers is to their and his discredit:

I have been taught, that there are only two ways to come at the Affections. One by the Senses and Imagination:... The other is, by the Reason and Judgement; ... Now I believe your Affections are moved in the first way very often; by melting Tones, pretty Similitudes .... And the truth is, you are like to be moved very seldom in our Churches by these means. For the better sort of Hearers are now out of love with these things: nor do they think there is any power either in a puling or whining, or in a roaring and tearing Voice. But if you can be moved by such strength of Reason as can conquer the Judgment, and so pass to demand submission from the Affections, you may find Power enough, I think, in our Pulpits. ${ }^{6}$

\footnotetext{
${ }^{64}$ The scenario for the production of this work is a debate over the problem of nonconformity: John Eachard, A free and impartial inquiry into the causes of that very great esteem and honour that the Nonconforming preachers are generally in with their followers, London ${ }^{6} 673$ (Wing E.49B), I8-19, 6-г.

${ }_{65}$ On Latitudinarian preaching and the evolution of the new style of sermon in the I670s, to which many critics have been sympathetic, see Isabel Rivers, Reason, grace and sentiment: a study of the language of religion and ethics in England, I660-I780, Cambridge I99 I, i. 49-59; Jackson I. Cope, foseph Glanvill, Anglican apologist, St Louis I 956, I 44-66. On the polemical uses of moderation and reasonableness see Richard Ashcraft, 'Latitudinarianism and toleration: historical myth versus political history', in Richard Kroll, Richard Ashcraft and Perez Zagorin (eds), Philosophy, science, and religion in England, I640-I70o, Cambridge I992, I 5 I-77, I 55-62; Brian Vickers, 'The Royal Society and English prose style: a reassessment', in Rhetoric and the pursuit of truth: language change in the seventeenth and eighteenth centuries: papers read at the Clark Library Seminar, 8 March I98o, by Brian Vickers, Nancy S. Streuever, Los Angeles I 985, 3-76.

${ }_{66}$ Simon Patrick, A friendly debate between a Conformist and a Nonconformist, London i669 (Wing P.798a), I5-16. See also Eachard, A free and impartial inquiry, I 12-13; Joseph Glanvill, An essay on preaching, London 678 (Wing G.808), 54-8.
} 
This clearly demonstrates the discontinuity of their preaching theory from the pre-Civil War English Reformed tradition. By reintroducing the dichotomy between persuasion through the reason or the passions, and placing the power to persuade firmly in the hands of the preacher, Patrick negates the operation of the Spirit in the delivery or the hearing of sermon. When Patrick's Nonconformist debater says that an understanding of the Gospel is gained when it 'shines into our mind with its light', an unexceptional formulation of the way in which the Spirit illuminates the mind, Patrick's conformist speaker replies 'These are Phrases which I would have you explain, if you can' ${ }^{67}$

The conformist polemicists dismiss the art of preaching used in the preCivil War Church along with that of their Nonconformist contemporaries. This is sometimes explicit: in The grounds and occasions of the contempt of the clergy, John Eachard ridicules the use of rhyming in the division of the text and gives as an example of this abuse a quotation from Thomas Adams. He also ridicules the simile of the (triangular) heart and the Trinity used by the famous Elizabethan preacher Thomas Playfere. ${ }^{68}$

There can be no better example of the changes in methods of sermon composition that accompanied this doctrinal shift than the changes made by John Wilkins to the later editions of his preaching handbook Ecclesiastes. Wilkins's Puritan upbringing, his prominence in the early Restoration Church and the popularity of Ecclesiastes in its various editions make him a central character in the evolution of the new essaylike plain style of preaching. ${ }^{69}$ The five editions of Ecclesiastes before r 669 all follow the English Reformed theory of preaching outlined above. Wilkins describes the various tasks involved in explicating the text and applying it to the hearers. The i669 edition (the last edition edited by Wilkins) advises the preacher to expound his text and then state "the true sense and meaning of the subject to be insisted upon'. The explication of the text by this method is merely the pretext for an oration introduced after the scriptural text has been discussed.$^{70}$ The doctrines do not arise directly from his interpretation of the biblical text, and so the intimate

${ }^{67}$ Patrick, A friendly debate, 7. This metaphor was used by, among others, Ralph Cudworth in his anti-Calvinist sermon to the House of Commons: A sermon preached before the honourable House of Commons, Cambridge i647 (Wing C.7469), 39-40.

68 John Eachard, The grounds and occasions of the contempt of the clergy, London I670 (Wing E.50), 67-8, 6r ; Thomas Adams, The blacke saint, in Works, 352; Thomas Playfere, Hearts delight: a sermon preached at Pauls Crosse, London i633 (RSTC 200 I3), 40-I.

${ }_{69}$ On Wilkins and Ecclesiastes see Barbara Shapiro, fohn Wilkins I6I4-I672: an intellectual biography, Berkeley, CA. I969, 70-9.

70 John Wilkins, Ecclesiastes, London I646, 5, I 2-I3; Ecclesiastes, '5th' edn, London I669 (Wing W.2 I93), 8-9, 2I-3. This is the single biggest change made to the text of Ecclesiastes. The other major change made to the text is in the section on confirmation, in which the post- 669 edition gives far more weight to proofs from human reasoning. On Ecclesiastes's publication history see Rivers, Reason, grace and sentiment, $3^{8-} 4^{0 .}$ 
relationship between the Word, the Spirit, the preacher and hearer established by the English Reformed theory is demolished.

It should be clear from this description why the theological changes that came with the Restoration of the Established Church would coincide with a fundamental change in preaching style. The plain style of the i67os is the conversational genus humile of classical oratory, and has, therefore, very little in common with the plainness advocated by the English Reformed method of the pre-Civil War period. With their abandonment of the charismatic element and strict scripturalism of the Reformed teachings on the Word, ${ }^{71}$ the conformist writers on preaching could reintroduce the classical arguments for persuasion. Clearly, only such a profound change in the Church's understanding of the function of preaching, and the theology on which it rests, could explain why those practising the style of the pre-Civil War Puritans could become the passionate wordsters and the conformable preachers the practitioners of a dialectical plain style. It is the Latitudinarians' use of the these terms of description that in many ways has legitimated modern scholars' dismissal of the 'prolixity' and 'metaphysical complexity' of pre-Civil War preaching and their association of the Restoration 'plain style' with a rationalist, scientific mentality. ${ }^{72}$

This article is necessarily only an outline of the complex history of preaching theories and methods in the seventeenth-century English Church, but it tries to demonstrate the importance of reading these texts according to the criteria by which they were produced before attempting to show their ideological or political significance. In order to understand the stylistic subtleties of seventeenth-century preaching, and the real points at issue in the debates over the styles best suited to the pulpit, we

\footnotetext{
${ }^{71}$ On the change in the theology of the Anglican Church from the predominant Calvinism soteriology to various forms of 'moralism' see John Spurr, The Restoration Church of England, New Haven i 99 I, 296-326.

72 Obviously the association of the Latitudinarians with the 'plain style' after the war is problematic for those who also argue for the Puritan's use of the same 'plain style' before the war. In I92 I Morris Croll associated Puritans and the rise of science with the 'Attic style' of prose, but did not attempt to explain why the only 'temporary' success of Puritanism was instrumental in the triumph of the 'Attic style': John M. Wallace, " Attic Prose" in the seventeenth century', in J. Max Patrick and Robert O. Evans (eds), Style, rhetoric and rhythm: essays by Morris $W$. Cross, Princeton i 966, 5 I-I I I, 67. Ten years later Richard Foster Jones explicitly linked the evolution of the new preaching style with the Royal Society and the rise of a modern, rationalist mentality: "The attack on pulpit eloquence in the Restoration: an episode in the development of the neo-classical standard for prose', in The seventeenth century: studies in the history of English thought and literature from Bacon to Pope, Stanford i95I, I I I-42. Robert Adolph recognised the Puritan pleas for plainness before the war and gave neither science nor Latitudinarianism priority in the evolution of the new 'plain style', but assumed that both were part of the same cultural movement: The rise of modern prose style, Cambridge, Mass. i 968, esp. pp. i9o-2 Io.
} 
$706 \quad$ MARY MORRISSEY

must abandon the anachronistic distinction between the 'Puritan plain' and the 'metaphysical' styles. As we understand so little of the theories of preaching in accordance with which these sermons were composed, we are not well-placed to determine what their characteristics imply for the politics, ideologies or theologies of the writers. 